\title{
HUBUNGAN KARAKTERISTIK, PENGETAHUAN TENTANG ASUPAN NATRIUM DAN CAIRAN DENGAN INTERDIALYTIC WEIGHT GAIN (IDWG) PADA PENDERITA GAGAL GINJAL KRONIK YANG MENJALANI HEMODIALISIS (HD)
}

\author{
Endang Sri Wahyuni ${ }^{1}$, Siti Indarti ${ }^{2}$
}

1Prodi Gizi Poltekkes Tanjung Karang, Bandar Lampung, Indonesia. Email: end_wahyuni71@poltekkes-tjk.ac.id 2STIKes Muhammadiyah Pringsewu, Lampung, Indonesia. Email: indarti.siti74@gmail.com

\section{ABSTRACT: DIETARY SODIUM INTAKE: KNOWLEDGE AND INTERDIALYTIC WEIGHT GAIN IN HEMODIALYSIS PATIENTS IN LAMPUNG PROVINCE- INDONESIA}

Background: A total of $44 \%$ of deaths in patients CKD on HD are caused by cardiovascular disease that related to uncontrolled interdialytic weight gain (IDWG). The IDWG increase is due to excessive sodium and fluid intake. This study aims to determine the relationship between characteristics and level of knowledge about fluid intake and sodium with IDWG.

Methods:This study was a cross sectional study with a total sample of 74 people with CKD on HD twice a week in RSUD Dr H Abdul Moeloek Lampung in 2018 who were determined by purposive sampling.

Results:The majority of respondents were male $(63.5 \%)$ with educational background were elementary / junior high school (33.8\%), jobs were laborers $(25.7 \%)$ and $70,27 \%$ ever get nutritional counseling. The average increase in IDWG weight is $2.0015 \pm 1.2537 \mathrm{~kg}$ with an average percentage of IDWG of $3.569 \pm 2.34 \%$. The result of statistic test showed no significant correlation between sex $(p=0.099)$, age $(p=0.709)$, education $(p=0.565)$, counseling status $(p=0.649)$, level of knowledge about sodium intake $(p=0.109)$ and fluid intake $(p=0.799)$ with IDWG. More intensive education and motivation by dietitian are needed in order to increase the knowledge of CKD on HD patient about food / drink that high in sodium and fluids also how to control thirst, sodium and fluid intake.

\section{Keywords: Characteristics, knowledge of fluid intake, knowledge of natrium intake, interdialytic weight gain}

PENDAHULUAN: Sebanyak 44\% kematian pada pasien GGK on hemodialisis disebabkan oleh penyakit kardiovaskuler yang berhubungan dengan interdialytic weight gain (IDWG) yang tidak terkontrol. Kenaikan IDWG sebagai akibat asupan natrium dan cairan yang berlebihan. Penelitian ini bertujuan untuk mengetahui hubungan antara karakteristik, tingkat pengetahuan tentang asupan cairan dan natrium dengan IDWG.

METODE: Penelitian ini menggunakan rancangan cross sectional dengan sampel berjumlah 74 orang penderita GGK yang menjalani HD 2 kali seminggu di RSUD Dr H Abdul Moeloek Lampung tahun 2018 yang ditentukan secara purposive sampling.

HASIL:Responden terbanyak adalah laki-laki $(63,5 \%$, pendidikan SD/SMP $(33,8 \%)$, pekerjaan buruh $(25,7 \%)$ dan pernah mendapat konseling gizi $(70,27 \%)$. Rata-rata IDWG sebesar 2,0015 $\pm 1,2537 \mathrm{~kg}$ dengan IDWG rata-rata $3,569 \pm 2,341 \%$. Hasil uji Chi Square menunjukkan tidak ada hubungan yang bermakna antara jenis kelamin $(p=0,099)$, usia $(p=0,709)$, pendidikan $(p=0,565)$, status konseling $(p=0,649)$, tingkat pengetahuan tentang asupan natrium $(p=0,109)$ dan asupan cairan $(p=0,799)$ dengan (IDWG). Edukasi dan motivasi yang lebih intensif oleh ahli gizi diperlukan dalam rangka meningkatkan pengetahuan pasien GGK on HD tentang bahan makanan/minuman tinggi natrium dan cairan serta cara mengendalikan asupan natrium, cairan dan rasa haus.

\section{Kata Kunci : karakteristik, pengetahuan asupan cairan, pengetahuan asupan natrium, IDWG}

\section{PENDAHULUAN}

Hemodialisa (HD) merupakan salah satu terapi bagi pasien GGK dan menjadi jenis terapi terbanyak yang diberikan oleh renal unit. Berdasarkan data Centers for Disease and Control Preventions (CDC), pada tahun 2014 terdapat 118,000 orang di Amerika
Serikat menjalani pengobatan penyakit ginjal tahap akhir.

Selain itu, data Indonesian Renal Registry (IRR) mencatat bahwa pada tahun 2015 terdapat sekitar 30.554 pasien yang secara aktif mejalani hemodialisis secara rutin (Anjarwati, 2018). 
HUBUNGAN KARAKTERISTIK, PENGETAHUAN TENTANG ASUPAN NATRIUM DAN CAIRAN DENGAN INTERDIALYTIC WEIGHT GAIN (IDWG) PADA PENDERITA GAGAL GINJAL KRONIK YANG MENJALANI HEMODIALISIS (HD)

Kematian pada pasien yang menjalani hemodialisis selama tahun 2015 tercatat sebanyak 1.243 orang dengan lama hidup dengan HD 1-317 bulan.

Proporsi terbanyak pada pasien dengan lama hidup dengan HD 6-12 bulan (Data Pusat dan Informasi Kementerian Kesehatan Republik Indonesia, 2017). Penyakit kardiovaskuler merupakan salah satu penyebab utama morbiditas dan mortalitas pada pasien gagal ginjal kronik (Echder \& Schriner, 2012). Penyebab gangguan sistem kardiovaskuler diantaranya adalah kontrol interdialytic weight gain (IDWG) yang buruk. Kandungan natrium dan cairan yang berlebih dalam tubuh sebagai awal dari kontrol IDWG yang buruk (Lolyta \& Solechan, 2012). Prevalensinya sebanyak $60-80 \%$ pasien meninggal akibat kelebihan intake cairan dan makanan pada periode interdialitik (Istanti, 2016).

IDWG adalah pertambahan berat badan diantara dua waktu dialisis. Pertambahan berat badan dihitung berdasarkan berat badan sebelum hemodialisa dikurangi dengan berat badan setelah hemodialisa (berat badan kering). Berat badan kering adalah berat badan terendah yang dicapai pasien tanpa disertai gejala retensi cairan (Lindley, 2009). Kenaikan IDWG terjadi karena ginjal tidak bisa mengekresikan kelebihan asupan natrium dan cairan yang berasal dari makanan dan minuman sehari-hari sehingga fungsi ekskresi ginjal digantikan oleh mesin hemodialisa.

Pusat Penelitian Penyakit Ginjal di California menemukan bahwa $86 \%$ pasien yang menjalani hemodialisa memiliki berat badan interdialitik lebih dari $1,5 \mathrm{~kg}$ (Kamyar, 2009). Peningkatan IDWG yang melebihi $5 \%$ dari berat badan kering dapat menyebabkan berbagai macam komplikasi seperti hipertensi, hipotensi intradialisis, gagal jantung kongestif (Suharyanto \& Madjid, 2009). Adapun kenaikan berat badan $1 \mathrm{~kg}$ sama dengan 1 liter air yang dikonsumsi pasien (Lindberg, 2010). Kenaikan berat badan antar sesi hemodialisis yang dianjurkan yaitu antara 2,5 \% - 3,5 \% dari berat badan kering untuk mencegah risiko terjadinya masalah kardiovaskuler. Pertambahan berat badan di antara dua sesi hemodialisa yang dapat ditoleransi adalah 1,0 -1,5 kg. Sedangkan Eropa merekomendasikan IDWG tidak lebih dari 4\%-4,5\% dari berat badan kering (Vennegoor, 2009). Namun, yang dapat ditoleransi oleh tubuh adalah tidak lebih dari $3 \%$ dari berat kering (Neumann, Wagner, Menne, Brockers, Schmidt, Weitman, Rieken, \& Haller 2013).

IDWG Prevensinya sebanyak $66,7 \%$ penderita GGK dengan HD tidak patuh dengan asupan cairan serta memiliki IDWG > 6\% dari berat badan kering. Sebanyak $70 \%$ pasien mempunyai IDWG pada katagori bahaya, karena intake cairan yang berlebih sebagai akibat rasa haus, cuaca yang panas, dan keluarga tidak mengingatkan (Kurniawati, Widyawati, \& Mariyanti, 2019).

Natrium merupakan salah satu zat gizi yang dibatasi bagi pasien GGK dengan hemodialisis guna mengendalikan tekanan darah dan edema. Asupan tinggi natrium akan menimbulkan rasa haus yang selanjutnya mendorong pasien untuk minum. Hal ini dapat mengakibatkan kenaikan IDWG yang besar (Rahardjo, Susalit \& Suhardjono 2009).

Pasien GGK dengan hemodialisa yang anuria, untuk setiap 8 gram garam dapur yang dikonsumsi akan membutuhkan kurang lebih 1 liter air untuk memperoleh kadar $\mathrm{Na}$ serum dalam level normal (Lindley, 2009).

Sedangkan pasien yang membatasi garam $<6$ gram/ hari dan hanya minum ketika haus, pertambahan berat badan tidak lebih dari $0,8 \mathrm{~kg} / \mathrm{hari}$ (Maria, Puspita \& Sulistyowati, 2012) .Diketahui sebagian besar asupan natrium $(88,6 \%)$ lebih dari kebutuhan. Eropa merekomendasikan asupan natrium antara 5-6 gram/ hari (Vennegoor, 2009).

Terdapat kaitan antara tingkat pendidikan terhadap perilaku positif yang menjadi dasar pengertian atau pemahaman dan perilaku dalam diri seorang individu (Azwar, 2007). Tingkat pendidikan sering dihubungkan dengan pengetahuan, dimana seseorang yang berpendidikan tinggi diasumsikan lebih mudah menyerap informasi (Notoatmodjo, 2010). Semakin rendah pengetahuan seseorang tentang kesehatan maka praktek tentang perilaku hidup sehat semakin rendah.

Tidak ada pengaruh yang signifikan antara tingkat pendidikan dengan IDWG. Hal ini menunjukkan bahwa kemampuan melakukan pengelolaan IDWG kemungkinan dipengaruhi faktor lain seperti adanya hasil interaksi antara pengetahuan, sikap dan tindakan pasien diperoleh

Endang Sri Wahyuni' Prodi Gizi Poltekkes Tanjung Karang, Bandar Lampung, Indonesia.

Email: end_wahyuni71@poltekkes-tjk.ac.id

Siti Indarti ${ }^{2}$ STIKes Muhammadiyah Pringsewu, Lampung, Indonesia. Email: indarti.siti74@gmail.com 
HUBUNGAN KARAKTERISTIK, PENGETAHUAN TENTANG ASUPAN NATRIUM DAN CAIRAN DENGAN INTERDIALYTIC WEIGHT GAIN (IDWG) PADA PENDERITA GAGAL GINJAL KRONIK YANG MENJALANI HEMODIALISIS (HD)

melalui pengalaman sendiri, orang lain, atau sumber informasi lain seperti media (Mustikasari, 2017).

\section{METODE PENELITIAN}

Penelitian ini menggunakan rancangan cross sectional dengan variabel independen pengetahuan tentang asupan cairan dan natrium, serta variabel dependen Interdialitic Weight Gain (IDWG). Populasi adalah penderita GGK yang menjalani hemodialisa di RSUD dr $\mathrm{H}$ Abdul Moeloek Provinsi Lampung dengan jumlah responden 74 orang. Kriteria sampel adalah pasien GGK yang sudah menjalani hemodialisa rutin 2 kali/minggu, minimal selama 2 bulan, berumur $>15 \quad-75$ tahun, dapat berkomunikasi dengan baik, bersedia sebagai responden dalam penelitian.Pemilihan sampel ditentukan berdasarkan purposive sampling. Data tingkat pengetahuan tentang asupan cairan dan natrium diperoleh dengan wawancara langsung menggunakan kuesioner. Sedangkan data IDWG (kenaikan berat badan interdialisa) diperoleh dari penimbangan berat badan sebelum dialisis dikurangi dengan berat badan kering pada periode dialisis sebelumnya

\section{HASIL}

\section{Karakteristik Responden}

Responden terbanyak berjenis kelamin pria sebanyak 47 responden $(63,5 \%)$. Dengan rentang usia terbanyak rentang 41-60 tahun yaitu sebanyak 48 responden $(64,87 \%)$, Berdasarkan tingkat pendidikan, responden paling banyak berpendidikan SD/SMP yaitu 31 responden (41,89\%). Sebagian besar responden mempunyai tingkat pengetahuan tentang asupan natrium dalam kategori cukup yaitu sebanyak 50 responden $(67,57 \%)$ dan pengetahuan tentang asupan cairan dalam kategori cukup sebanyak 45 responden $(60,81 \%)$. Responden yang telah mendapat konseling gizi sebanyak 52 responden $(70,30 \%)$ dan sebanyak 40 responden $(54,05 \%)$ mempunyai kenaikan berat badan interdialisis (IDWG) $>3 \%$. Karakteristik responden selengkapnya dapat dilihat pada tabel 1

Endang Sri Wahyuni' Prodi Gizi Poltekkes Tanjung Karang, Bandar Lampung, Indonesia.

Email: end_wahyuni7ı@poltekkes-tjk.ac.id

Siti Indarti ${ }^{2}$ STIKes Muhammadiyah Pringsewu, Lampung, Indonesia. Email: indarti.siti74@gmail.com 
HUBUNGAN KARAKTERISTIK, PENGETAHUAN TENTANG ASUPAN NATRIUM DAN CAIRAN DENGAN INTERDIALYTIC WEIGHT GAIN (IDWG) PADA PENDERITA GAGAL GINJAL KRONIK YANG MENJALANI HEMODIALISIS (HD)

Tabel 1. Distribusi Frekuensi karakteristik responden yang menjalani Hemodialisa $\mathrm{N}=74$

\begin{tabular}{|c|c|c|}
\hline \multirow{2}{*}{ Karakteristik } & \multicolumn{2}{|c|}{ Jumlah } \\
\hline & $\mathrm{n}$ & $\%$ \\
\hline \multicolumn{3}{|l|}{ Jenis Kelamin } \\
\hline - Pria & 47 & 63,50 \\
\hline - Wanita & 27 & 36,50 \\
\hline \multicolumn{3}{|l|}{ Umur } \\
\hline$-17-20$ th & 1 & 1,35 \\
\hline$-21-40$ th & 17 & 22,97 \\
\hline$-41-60$ th & 48 & 64,87 \\
\hline$->60$ th & 8 & 10,81 \\
\hline \multicolumn{3}{|l|}{ Pendidikan } \\
\hline$-\mathrm{SD} / \mathrm{SMP}$ & 31 & 41,89 \\
\hline - SMA & 25 & 33,79 \\
\hline - PT & 18 & 24,32 \\
\hline \multicolumn{3}{|l|}{ Status konseling gizi } \\
\hline - Belum pernah & 22 & 70,27 \\
\hline - Pernah & 52 & 29,73 \\
\hline \multicolumn{3}{|c|}{ Pengetahuan tentang asupan natrium } \\
\hline \multicolumn{3}{|c|}{ Kurang } \\
\hline Cukup & 13 & 17,57 \\
\hline - Baik & 50 & 67,57 \\
\hline & 11 & 14,86 \\
\hline \multicolumn{3}{|l|}{ Pengetahuan asupan cairan } \\
\hline \multicolumn{3}{|l|}{ Kurang } \\
\hline Cukup & 20 & 27,03 \\
\hline - Baik & 45 & 60,81 \\
\hline & 9 & 12,16 \\
\hline \multicolumn{3}{|l|}{ IDWG } \\
\hline - > $3 \%$ BB kering & 40 & 54,05 \\
\hline$-\leq 3 \%$ BB kering & 34 & 45,95 \\
\hline
\end{tabular}

Hasil uji chi square menunjukkan tidak ada hubungan yang bermakna antara jenis kelamin $(p=0,099)$, usia $(p=$ $0,709)$, tingkat pendidikan $(p=0,565)$, status konseling gizi $(p=0,649)$ dengan besarnya IDWG. Responden dengan tingkat pengetahuan tentang asupan natrium dalam katagori baik dan IDWG $\leq 3 \%$ sebanyak 6 responden $(54,55 \%)$. Sedangkan responden dengan tingkat pengetahuan dalam kategori kurang dan IDWG $\leq 3 \%$ sebanyak 9 responden $(69,23 \%)$. Uji chi square menunjukkan tidak ada hubungan antara tingkat pengetahuan tentang asupan natrium dengan IDWG $(\mathrm{p}=0,109)$. Responden dengan tingkat pengetahuan tentang asupan cairan dalam kategori baik dan IDWG $\leq 3 \%$ sebanyak 4 responden $(44,44 \%)$. Sedangkan responden dengan tingkat pengetahuan dalam katageri kurang dan IDWG $\leq 3 \%$ sebanyak 8 responden (40\%). Hasil uji chi square menunjukkan tidak ada hubungan antara

Endang Sri Wahyuni' Prodi Gizi Poltekkes Tanjung Karang, Bandar Lampung, Indonesia.

Email: end_wahyuni71@poltekkes-tjk.ac.id

Siti Indarti ${ }^{2}$ STIKes Muhammadiyah Pringsewu, Lampung, Indonesia. Email: indartisiti74@gmail.com 
HUBUNGAN KARAKTERISTIK, PENGETAHUAN TENTANG ASUPAN NATRIUM DAN CAIRAN DENGAN INTERDIALYTIC WEIGHT GAIN (IDWG) PADA PENDERITA GAGAL GINJAL KRONIK YANG MENJALANI HEMODIALISIS (HD)

tingkat pengetahuan tentang asupan cairan dengan IDWG $(p=0,799)$. Hasil selengkapnya untuk uji bivariat dapat dilihat pada tabel 2

Tabel 2. Hubungan Karakteristik, Pengetahuan Tentang Asupan Natrium Dan Cairan Dengan Interdialytic Weight Gain (IDWG) N=74

\begin{tabular}{|c|c|c|c|c|c|c|c|}
\hline \multirow{3}{*}{ Karakteristik } & \multicolumn{4}{|c|}{ IDWG } & \multirow{2}{*}{\multicolumn{2}{|c|}{ Total }} & \multirow{3}{*}{$p$-value } \\
\hline & \multicolumn{2}{|c|}{$>3 \%$} & \multicolumn{2}{|c|}{$\leq 3 \%$} & & & \\
\hline & $\mathrm{n}$ & $\%$ & $\mathrm{n}$ & $\%$ & $\mathbf{N}$ & $\%$ & \\
\hline \multicolumn{8}{|l|}{ Jenis kelamin } \\
\hline - Pria & 22 & 46,80 & 25 & 53,20 & 47 & 100 & 0,099 \\
\hline - wanita & 18 & 66,67 & 9 & 33,33 & 27 & 100 & \\
\hline Total & 40 & 54,05 & 34 & 45,95 & 74 & 100 & \\
\hline \multicolumn{8}{|l|}{ Usia } \\
\hline$->60 \%$ & 4 & 50,00 & 4 & 50,00 & 8 & 100 & \\
\hline$-41-60$ th & 26 & 54,17 & 22 & 45,83 & 48 & 100 & 0,709 \\
\hline$-21-40$ th & 10 & 58,82 & 7 & 41,18 & 17 & 100 & \\
\hline$-17-20$ th & 0 & 0 & 1 & 100,00 & 1 & 100 & \\
\hline Total & 40 & 54,05 & 34 & 45,95 & 74 & 100 & \\
\hline \multicolumn{8}{|l|}{ Pendidikan } \\
\hline - SD/SMP & 19 & 61,29 & 12 & 38,71 & 31 & 100 & \\
\hline - SMA & 12 & 48,00 & 13 & 52,00 & 25 & 100 & 0,565 \\
\hline - PT & 9 & 50,00 & 9 & 50,00 & 18 & 100 & \\
\hline Total & 40 & 54,05 & 34 & 45,95 & 74 & 100 & \\
\hline \multicolumn{8}{|l|}{ Status konseling } \\
\hline - Belum pernah & 11 & 50,00 & 11 & 50,00 & 22 & 100 & 0,649 \\
\hline - Pernah & 29 & 55,77 & 23 & 44,23 & 52 & 100 & \\
\hline Total & 40 & 54,05 & 34 & 45,95 & 74 & 100 & \\
\hline \multicolumn{8}{|c|}{ Pengetahuan tentang asupan $\mathrm{Na}$} \\
\hline - Kurang & 4 & 30,77 & 9 & 69,23 & 13 & 100 & \\
\hline - Cukup & 31 & 62,00 & 19 & 38,00 & 50 & 100 & 0,109 \\
\hline - Baik & 5 & 45,45 & 6 & 54,55 & 11 & 100 & \\
\hline Total & 40 & 54,05 & 34 & 45,95 & 74 & 100 & \\
\hline \multicolumn{8}{|c|}{ Pengetahuan tentang asupan cairan } \\
\hline - Kurang & 12 & 60,00 & 8 & 40,00 & 20.4 & 100 & \\
\hline - Cukup & 23 & 51,11 & 22 & 48,89 & 5 & 100 & 0,709 \\
\hline - Baik & 5 & 55,56 & 4 & 44,44 & 9 & 100 & \\
\hline Total & 40 & 54,05 & 34 & 45,95 & 74 & 100 & \\
\hline
\end{tabular}

Endang Sri Wahyuni' Prodi Gizi Poltekkes Tanjung Karang, Bandar Lampung, Indonesia.

Email: end_wahyuni71@poltekkes-tjk.ac.id

Siti Indarti ${ }^{2}$ STIKes Muhammadiyah Pringsewu, Lampung, Indonesia. Email: indarti.siti74@gmail.com 
HUBUNGAN KARAKTERISTIK, PENGETAHUAN TENTANG ASUPAN NATRIUM DAN CAIRAN DENGAN INTERDIALYTIC WEIGHT GAIN (IDWG) PADA PENDERITA GAGAL GINJAL KRONIK YANG MENJALANI HEMODIALISIS (HD)

\section{PEMBAHASAN}

\section{Interdialytic Weight Gain (IDWG)}

IDWG adalah peningkatan volume cairan yang dimanifestasikan dengan peningkatan berat badan selama periode interdialitik (diantara dua sesi dialisis). IDWG yang dapat ditoleransi oleh tubuh adalah $\leq 3 \%$ dari berat kering (Neumann, Wagner, Menne, Brocker, Schmidt, Weitmann, Rieken \& Haller, 2013). Terjadinya peningkatan risiko kematian pada responden dengan IDWG $\geq 5,7 \%$ bila dibandingkan responden dengan IDWG 2,5 - 3,99\%. (Wong, Cullough, Bieber, Bommer, Hecking, Levin \& Tomo, 2017). Demikian juga risiko untuk perawatan di rumah sakit karena kelebihan cairan akan meningkat pada responden dengan IDWG $\geq 4 \%$ dibandingkan IDWG 2,5-3,99\%.

Responden adalah 74 orang penderita GGK yang sudah 2 bulan menjalani hemodialisa rutin 2 kali/minggu, dengan lama dialisis antara 3-4 jam pada setiap sesi dialisis. Rata-rata IDWG responden adalah $2,0014 \mathrm{~kg} \pm 1,2537 \mathrm{~kg}$, dengan persentase kenaikan 3,569 $\pm 2,341 \%$.dari berat badan kering. Adapun IDWG terendah $0 \mathrm{~kg}$ dan tertinggi $5 \mathrm{~kg}$ atau terendah $0 \%$ dan tertinggi $11,11 \%$. . Responden dengan IDWG $>3 \%$ sebanyak 40 responden $(54,1 \%)$.

Rata-rata IDWG responden sebesar 5,3 $\pm 0,9 \%$ (Bossola, Pepe \& Vulpio 2018). Rata-rata IDWG responden sebesar 4,00 $\pm 1,89 \%$ (Istanti, 2013). Jika dibandingkan kedua penelitian tersebut, rata-rata IDWG responden dalam penelitian ini lebih kecil.

Perbedaan bisa disebabkan karena dalam penelitian ini terdapat beberapa responden dengan IDWG $0 \%$ sebagai akibat diuresis yang masih baik sehingga kelebihan cairan masih bisa dieksresi oleh ginjal. Responden dengan IDWG $<0 \%$ mengalami defisiensi energi dan protein ataupun mengalami sakit yang berulang (Wong, Cullough, Bieber, Bommeer, Hecking, Levin \& Tomo 2017).

\section{Jenis Kelamin}

Responden banyak yang berjenis kelamin pria dibandingkan dengan wanita. menunjukkan bahwa pasien GGK yang menjalani hemodialisis di RSUD Dr.Moewardi Surakarta lebih banyak pria dengan jumlah 78 responden $(58,2 \%)$ (Hartini \& Sulastri, 2016). Demikian juga penelitian sebelumnya yang menyatakan 30 responden $(62,5 \%)$ yang menjalani hemodialisa berjenis kelamin laki-laki (Istanti, 2013). Pria lebih rentan terkena gangguan ginjal daripada wanita, sehubungan dengan gaya hidup laki-laki lebih berisiko terkena GGK karena kebiasaan merokok dan minum alkohol yang dapat menyebabkan ginjal bekerja keras (Agustini, 2010).

Berdasarkan jenis kelamin, sebanyak 9 responden wanita $(33,33 \%)$ mempunayi IDWG $\leq 3 \%$ dan 25 responden pria $(53,20 \%)$ mempunyai IDWG $\leq 3 \%$. Persentase pria dengan IDWG $\leq 3 \%$ lebih banyak daripada wanita. Hal ini disebabkan pria sebagai tulang punggung dalam keluarga, lebih terpacu untuk lebih menjaga kualitas hidupnya.

Penambahan nilai IDWG yang terlalu tinggi dapat menimbulkan efek negatif terhadap tubuh diantaranya terjadi hipotensi, kram otot, sesak nafas, mual dan muntah (Moissl Arias-Guillen, Wabel,Fontsere, Carera, \& Campistol, 2013). Peningkatan IDWG yang melebihi $5 \%$ dari berat badan kering dapat menyebabkan komplikasi seperti hipertensi, hipotensi intradialisis, gagal jantung kongestif. Uji chi square menunjukkan tidak ada hubungan yang bermakna antara jenis kelamin dengan besarnya IDWG $(p=0,099)$ (Suharyanto \& Madjid, 2009).

\section{Usia}

Responden terbanyak pada rentang usia 41-60 tahun yaitu sebanyak 48 responden $(64,87 \%)$. Hasil penelitian ini sejalan dengan penelitian sebelumnya yang menyatakan bahwa jumlah pasien gagal ginjal kronik dengan usia 46-75 tahun sebanyak 70\% sedangkan usia 15-45 tahun sebesar 30\%.(Pranandari \& Supadmi, 2015).

Rata-rata usia pasien GGK yang menjalani hemodialisa adalah 48,46 $\pm 12,42$ tahun (Istanti, 2013).

Usia merupakan salah satu risiko gagal ginjal kronik. Hal ini di menunjukkan bahwa semakin bertambah usia, semakin berkurang fungsi ginjal karena disebabkan terjadinya penurunan kecepatan eksresi glomerulus dan penurunan fungsi ginjal.

Berdasarkan uji chi square menunjukkan tidak ada hubungan yang bermakna antara usia dengan besarnya IDWG $(p=0,709)$. Ini berarti bahwa semakin bertambahnya usia tidak membuat responden untuk

Endang Sri Wahyuni' Prodi Gizi Poltekkes Tanjung Karang, Bandar Lampung, Indonesia.

Email: end_wahyuni71@poltekkes-tjk.ac.id

Siti Indarti ${ }^{2}$ STIKes Muhammadiyah Pringsewu, Lampung, Indonesia. Email: indarti.siti74@gmail.com 
HUBUNGAN KARAKTERISTIK, PENGETAHUAN TENTANG ASUPAN NATRIUM DAN CAIRAN DENGAN INTERDIALYTIC WEIGHT GAIN (IDWG) PADA PENDERITA GAGAL GINJAL KRONIK YANG MENJALANI HEMODIALISIS (HD)

peduli dengan kenaikan berat badan antar dialisis. Hasil penelitian ini sesuai dengan penelitian sebelumnya yang menyatakan tidak ada hubungan antara usia dengan IDWG (Istanti, 2016). Demikian juga hasil penelitian yang menunjukkan tidak ada hubungan signifikan antara usia dengan IDWG (Mustikasari, 2017).

\section{Pendidikan}

Tingkat pendidikan responden yang paling banyak adalah SD/SMP yaitu 31 responden $(41,89 \%)$, diikuti SMA 25 responden $(33,79 \%)$. Hasil penelitian ini sesuai dengan penelitian sebelumnya yang menyatakan bahwa tingkat pendidikan terbanyak pada pasien GGK yang menjalani hemodialisa adalah SD/SMP yaitu sebanyak 37,7\% (Wulan \& Emaliyawati, 2018). Hasil penelitian lain juga mengemukakan bahwa pasien GGK yang menjalani hemodialisa di RSU Dr. Zainoel Abidin

Banda Aceh paling banyak pada kategori berpendidikan rendah/dasar yaitu sebanyak 24 orang (38,1\%).( Rukmaliza, 2014).

Hasil penelitian ini tidak jauh berbeda dengan penelitian di RS Hasan Sadikin Bandung yang menunjukkan bahwa responden terbanyak pada tingkat pendidikan SD/SMP yaitu sebesar $37,7 \%$ (Wulan \& Emaliyawati, 2018).

Pendidikan sering dikaitkan dengan pengetahuan dan status sosial, pendidikan yang rendah sering dikaitkan dengan kurangnya pengetahuan dan kurangnya akses tehadap pelayanan kesehatan. Kurangnya pengetahuan dan kesadaran masyarakat untuk deteksi dini dalam memeriksakan dirinya ke pusat pelayanan kesehatan menjadi penyebab meningkatnya pasien GGK dikarenakan pada stadium awal tidak ada keluhan yang spesifik (Notoatmodjo ,2010).

Semakin tinggi pendidikan seseorang maka akan semakin cepat memahami tentang kondisi penyakit yang dialami, seseorang yang memiliki pendidikan lebih tinggi akan lebih mudah untuk menyerap informasi, mampu menjaga dirinya karena pengetahuannya yang lebih dibandingkan dengan orang yang memiliki pendidikan rendah.

Dengan demikian semakin tinggi tingkat pendidikan, kemampuan untuk menerima informasi lebih baik. (Notoatmodjo, 2010).
Berdasarkan uji chi square menunjukkan tidak ada hubungan yang bermakna antara tingkat pendidikan dengan besarnya IDWG ( $p=0,565)$. Hasil ini sesuai dengan penelitian sebelumnya yang menyatakan bahwa tidak ada hubungan yang bermakna antara tingkat pendidikan dengan IDWG $(p=0,808)$ (Istanti,2016). Di RSUD Panembahan Bantul juga menunjukkan tidak ada hubungan yang bermakna antara tingkat pendidikan dengan IDWG (Mustikasari, 2017).

Hal ini menunjukkan bahwa penggendalian IDWG pada responden lebih dipengaruhi oleh faktor lain seperti sikap dan perilaku pasien terkait asupan cairan dan natrium, yang diperoleh dari pengalaman sendiri, orang lain, maupun media informasi lainnya

\section{Status Konseling Gizi}

Konsultasi gizi merupakan salah satu cara untuk meningkatkan pengetahuan penderita GGK yang menjalani hemodialisa. Responden yang sudah pernah mendapatkan konseling gizi oleh ahli gizi sebanyak 52 responden $(70,27 \%)$.

Konseling gizi adalah serangkaian kegiatan sebagai proses komunikasi dua arah antara konselor dan klien/pasien untuk menanamkan dan meningkatkan pengertian, sikap, dan perilaku sehingga membantu klien/pasien mengenal dan mengatasi masalah gizi yang sedang dihadapi. Tujuannya adalah untuk membantu pasien mengubah perilaku dan sikap yang berkaitan dengan masalah gizi.

Hasil uji chi square menunjukkan bahwa tidak ada hubungan yang bermakna antara status konseling dengan besarnya IDWG $(p=0,649)$. Hasil ini bisa disebabkan karena responden yang belum mendapat konseling gizi memperoleh informasi terkait makanan dan minuman dari sumber informasi lain seperti buku, TV atau media lainnya. Sementara itu pada responden yang sudah pernah mendapat konseling gizi, mereka belum memahami materi konseling secara menyeluruh.

Beberapa responden menyatakan bahwa setelah mendapatkan konseling gizi, mereka dapat mengetahui tujuan pengaturan makan serta cara mengatur makan dan minum agar status kesehatan menjadi lebih baik. Namun demikian, beberapa responden merasa tidak mendapatkan efek yang

Endang Sri Wahyuni' Prodi Gizi Poltekkes Tanjung Karang, Bandar Lampung, Indonesia.

Email: end_wahyuni71@poltekkes-tjk.ac.id

Siti Indarti ${ }^{2}$ STIKes Muhammadiyah Pringsewu, Lampung, Indonesia. Email: indarti.siti74@gmail.com 
HUBUNGAN KARAKTERISTIK, PENGETAHUAN TENTANG ASUPAN NATRIUM DAN CAIRAN DENGAN INTERDIALYTIC WEIGHT GAIN (IDWG) PADA PENDERITA GAGAL GINJAL KRONIK YANG MENJALANI HEMODIALISIS (HD)

diharapkan padahal mereka sudah merasa mengikuti anjuran diet. Hal ini bisa disebabkan karena responden belum mengetahui sepenuhnya aturan makan, mengingat sebagian besar responden baru mendapat konseling gizi sebanyak 1 kali. Sebagai contoh, sebanyak 12 responden $(23,08 \%)$ yang pernah mendapat konseling gizi, masih salah dalam menjawab jumlah cairan yang boleh dikonsumsi dalam sehari.

Pemahaman yang parsial terhadap aturan makan, mengakibatkan responden mengkonsumsi makanan/minuman yang sebenarnya tidak sesuai anjuran diet. tetapi responden merasa bahwa dia sudah mengikuti anjuran diet. Untuk itu perlu pendampingan ahli gizi berupa konseling gizi secara intensif pada pasien GGK yang menjalai hemodialisa. Pendampingan dapat dilakukan pada pasien yang masih awal dalam menjalani hemodialisa. Interaksi yang lebih intensif pada saat hemodialisa dapat menambah pengetahuan pasien tentang aturan makan sekaligus dapat memotivasi pasien untuk berkomitmen memperbaiki kualitas hidupnya melalui pengendalian IDWG.

\section{Pengetahuan tentang Asupan Natrium dan Cairan}

Sebanyak 50 responden $(67,57 \%)$ mempunyai pengetahuan asupan natrium dalam katagori cukup dan sebanyak 11 responden (14,87\%) dalam kategori baik. Pengetahuan tentang asupan natrium sangat penting bagi pasien GGK yang menjalani hemodialisis. Sebanyak 25 responden (33,78\%) tidak mengetahui batasan garam dapur yang boleh dikonsumsi dalam sehari. Asupan natrium pada pasien GGK yang melakukan terapi hemodialisis, dibatasi yaitu sebesar $1 \mathrm{~g}$ ditambah dengan $1 \mathrm{~g}$ untuk setiap 0,5 liter urine yang keluar dalam 24 jam terakhit (Almatsier, 2006).

Asupan natrium yang berlebih dapat mengakibatkan tingginya kadar natrium di dalam darah karena ginjal pada pasien GGK tidak bisa mengeluarkan kelebihan natrium dalam darah (Irianto, 2014) .

Kadar natrium darah yang lebih dari $145 \mathrm{mEq} / \mathrm{L}$ dapat menimbulkan gejala kebingungan, kejang otot, kejang seluruh tubuh, koma, dan kematian (Kristanti, 2006).
Asupan natrium yang tinggi akan mengakibatkan rasa haus yang mendorong responden untuk minum, yang mengakibatkan risiko peningkatan IDWG (Rahardjo, Susalit, \& Suhardjono, 2009).

Responden dengan tingkat pengetahuan tentang asupan natrium dalam kategori baik dan IDWG $\leq 3 \%$ sebanyak 6 responden (54,55\%). Sedangkan responden dengan kategori pengetahuan kurang dan IDWG $\leq 3 \%$ sebanyak 9 responden $(69,23 \%)$. Hasil uji chi square menunjukkan tidak ada hubungan antara tingkat pengetahuan tentang asupan cairan dengan IDWG $(p=0,109)$.

Hal ini bisa disebabkan karena pengetahuan yang baik tidak dibarengi dengan motivasi yang cukup. Responden mengetahui akibat asupan natrium yang berlebih, tetapi tidak berusaha untuk mengendalikan asupan natrium. Sebanyak 70 responden $(94,59 \%)$ dapat menjawab pertanyaan tentang akibat asupan natrium yang berlebih. Namun pengetahuan ini tidak diimbangi dengan motivasi pasien untuk mengetahui batasan garam dapur yang diperbolehkan dikonsumsi dalam satu hari. Masih terdapat 48 responden $(64,86 \%)$ yang tidak mengetahui akibat kelebihan asupan garam serta 22 responden $(29,73 \%)$ yang tidak mengetahui batasan asupan garam dapur yang diperbolehkan dalam sehari. Sebanyak 53 responden (71,62\%) salah dalam memilih makanan olahan yang rendah natrium dan tidak merangsang rasa haus.

Kurangnya pengetahuan responden tentang batasan asupan natrium, dapat mengakibatkan berlebihnya asupan natrium, asupan natrium yang tinggi merupakan faktor prediktor kematian pada pasien yang menjalani hemodialisa (Mc. Causland, Waikar, \& Bruneli, 2012). Asupan natrium yang berlebih akan mengakibatkan peningkatan osmolaritas cairan ekstra seluler dan menimbulkan munculnya rasa haus (Mann \& Stewart, 2012). Sebagian besar penderita GGK dengan hemodialisis tidak bisa menahan rasa haus sehingga tidak mempedulikan aturan masukan cairan yang diperbolehkan (Istanti, 2013).

Pasien GGK dengan hemodialisa yang anuria, untuk setiap 8 gram garam dapur yang dikonsumsi akan membutuhkan kurang lebih 1 liter air untuk memperoleh kadar $\mathrm{Na}$ serum dalam level normal, sedangkan pasien yang membatasi garam $<6 \mathrm{gram} /$

Endang Sri Wahyuni' Prodi Gizi Poltekkes Tanjung Karang, Bandar Lampung, Indonesia.

Email: end_wahyuni71@poltekkes-tjk.ac.id

Siti Indarti ${ }^{2}$ STIKes Muhammadiyah Pringsewu, Lampung, Indonesia. Email: indarti.siti74@gmail.com 
HUBUNGAN KARAKTERISTIK, PENGETAHUAN TENTANG ASUPAN NATRIUM DAN CAIRAN DENGAN INTERDIALYTIC WEIGHT GAIN (IDWG) PADA PENDERITA GAGAL GINJAL KRONIK YANG MENJALANI HEMODIALISIS (HD)

hari dan hanya minum ketika haus, pertambahan berat badan tidak lebih dari $0,8 \mathrm{~kg} / \mathrm{hari}$ (Lindley, 2009),. Adanya hubungan yang bermakna antara asupan garam dengan \%IDWG ( $p=0,000)$ (Nerbasa, Morais, Santos, Kruger, Sczip, \& Luz Filho, 2013).

Besarnya IDWG berhubungan dengan munculnya berbagai komplikasi seperti hipertensi, congestive heart failure, dan bahkan kematian (Kalantar,Regidor, Kovesdy, Van wyck, Bunnapradist, Horwich, \& Fonarow, 2009).

\section{Pengetahuan tentang asupan cairan}

Pada penderita GGK yang sudah mengalami anuria, asupan cairan sangat berpengaruh pada besarnya IDWG. Asupan cairan yang diperbolehkan untuk pasien GGK yang menjalani hemodialis adalah $500-700 \mathrm{ml}$ ditambah dengan urine yang keluar selama 24 jam. Sebanyak 50 responden $(67,57 \%)$ mempunyai pengetahuan tentang asupan cairan dalam kategori cukup. Sedangkan 13 responden $(17,57 \%)$ mempunyai pengetahuan dalam katageri kurang. Asupan cairan sangat berperan penting terhadap peningkatan berat badan interdialitik (IDWG) dimana asupan cairan yang berlebihan akan meningkatkan kelebihan cairan dalam tubuh karena fungsi ekskresi ginjal sudah mengalami banyak penurunan.

Responden dengan tingkat pengetahuan tentang asupan cairan dalam katagori baik dan IDWG $\leq 3 \%$ sebanyak 4 responden $(44,44 \%)$. Sedangkan responden dengan tingkat pengetahuan dalam katagori kurang dan IDWG $\leq 3 \%$ sebanyak 8 responden (40\%). Hasil uji chi square menunjukkan tidak ada hubungan yang bermakna antara tingkat pengetahuan tentang asupan cairan dengan kenaikan berat badan interdialisa $(p=0,799)$.

Terdapat hubungan yang signifikan antara intake cairan dan penambahan berat badan dimana semakin banyak masukan cairan maka berat badan interdialitik (IDWG) semakin meningkat $(p=0,000)$ (Istanti, 2016). Hasil penelitian Istanti menunjukkan bahwa faktor yang paling berpengaruh dalam peningkatan berat badan iterdialitik tersebut adalah intake cairan

Pengaturan asupan cairan yang baik dapat mencegah IDWG yang berlebihan. Sebagian besar responden mengetahui dampak dari asupan cairan yang berlebih. Sebanyak 58 responden $(78,38 \%)$ dapat menjawab pertanyaan tentang dampak asupan cairan yang berlebih. Namun demikian responden kurang mengetahui tentang alasan pembatasan cairan, terbukti sebanyak 50 responden $(67,57 \%)$ responden tidak mengetahui alasan pembatasan cairan.

Pengetahuan responden tentang dampak asupan cairan tidak diikuti dengan pengetahuan mengenai sumber cairan. Sebanyak 43 responden $(58,11 \%)$ menyatakan bahwa sumber cairan hanya berasal dari minuman. Sebagian besar responden juga belum mengetahui tentang teknik pengolahan untuk meminimalkan asupan cairan. Sebanyak 52 responden $(70,27 \%)$ belum mengetahui cara pengolahan snack yang aman dari risiko asupan cairan yang berlebih. Responden lebih banyak memilih cara memasak dengan direbus dan digoreng daripada dipanggang. Pengolahan dengan direbus dapat meningkatkan kandungan cairan dalam makanan. Sementara pengolahan dengan digoreng dapat merangsang rasa haus yang dapat mengakibatkan asupan cairan meningkat.

Strategi untuk membatasi IDWG adalah dengan mengurangi rasa haus, memperbaiki motivasi dan pengetahuan dalam rangka meningkatkan kepatuhan pada pembatasan cairan (Bassola, Pepe, \& Vulpio, 2018) . Sehubungan dengan hal tersebut di atas, ahli gizi perlu lebih intensif dalam memberikan edukasi ke pasien GGK dengan hemodialisa. Dengan demikian pasien dapat menanyakan setiap permasalahan terkait aturan makan dan pasien mendapat informasi rinci yang berkaitan dengan diet yang harus mereka jalani. Edukasi dapat diberikan dengan menggunakan gambar dan video.

Pemberian edukasi terstruktur dengan menggunakan gambar dan video dapat menurunkan IDWG $(p=0,04)$ (Wayunah, Saefulloh, \& Nuraeni, 2016).

Pasien GGK meskipun dengan kondisi hipervolemia, sering mengalami rasa haus yang berlebihan yang merupakan salah satu stimulus timbulnya sensasi haus. Rasa haus atau keinginan untuk minum disebabkan oleh berbagai faktor diantaranya masukan sodium, kadar sodium yang tinggi, penurunan kadar posatium, angiotensin II,

Endang Sri Wahyuni' Prodi Gizi Poltekkes Tanjung Karang, Bandar Lampung, Indonesia.

Email: end_wahyuni71@poltekkes-tjk.ac.id

Siti Indarti ${ }^{2}$ STIKes Muhammadiyah Pringsewu, Lampung, Indonesia. Email: indartisiti74@gmail.com 
HUBUNGAN KARAKTERISTIK, PENGETAHUAN TENTANG ASUPAN NATRIUM DAN CAIRAN DENGAN INTERDIALYTIC WEIGHT GAIN (IDWG) PADA PENDERITA GAGAL GINJAL KRONIK YANG MENJALANI HEMODIALISIS (HD)

peningkatan urea plasma, hipovolemia post dialisis dan faktor psikologis (Istanti, 2016).

Sebanyak 51 responden $(68,92 \%)$ tidak mengetahui alasan pembatasan cairan, 43 responden $(58,11 \%)$ tidak mengetahui bahwa cairan juga ada dalam makanan bukan hanya minuman dan 20 responden $(27,03 \%)$ tidak mengetahui batas maksimum asupan cairan dalam sehari. Sebanyak 29 responden $(39,19 \%)$ tidak mengetahui bahwa mengulum es batu dapat mengurani rasa haus. Sebanyak 35 responden $(47,30 \%)$ tidak bisa memilih snack dengan kandungan cairan yang rendah dan lebih memilih agar-agar sebagai jenis snack yang aman padahal kandungan cairannya tinggi.

Masih terdapat 48 responden $(60 \%)$ tidak mengetahui cara pengolahan bahan makanan untuk meminimalisir asupan cairan dan natrium.

Diperlukan edukasi dan motivasi yang lebih intensif oleh ahli gizi baik bagi pasien maupun keluarganya agar bisa ikut memantau makanan dan minuman yang responden konsumsi. Edukasi lebih dititikberatkan pada materi bahan makanan yang tinggi cairan dan natrium, jenis makanan yang dapat mengurangi rasa haus, jenis snack yang rendah kandungan cairan dan natrium, cara pengolahan guna mengendalikan asupan cairan dan natrium, dan jumlah maksimal penggunaan garam dapur dalam sehari.

\section{SIMPULAN}

Tidak terdapat hubungan yang bermakna antara karakteristik (jenis kelamin, usia, tingkat pendidikan,status konseling gizi, tingkat pengetahuan tentang asupan natrium dan cairan dengan IDWG. Ahli gizi perlu memberikan motivasi dan edukasi yang lebih intensif bagi pasien dan keluarganya tentang jenis makanan tinggi natrium dan cairan, cara mengendalikan asupan natrium dan cairan serta mengurangi rasa haus

\section{DAFTAR PUSTAKA}

Agustini, R. (2010). Dampak dukungan keluarga dalam mempengaruhi kecemasan pada pasien penderita gagal ginjal kronik di RS Panti Rapih Yogyakarta.
Almatsier, S. (2006). Penuntun Diet, edisi baru, Instalasi Gizi Perjan RS Dr. Cipto Mangunkusumo dan Asosiasi Dietisien Indonesia.

Anjarwati, A. (2018). Health Related-Quality of Life in CKD and Dialysis Patients in Asian Countries: A Systematic Review. Arkesmas (Arsip Kesehatan Masyarakat), 3(2), 50-55.

Azwar, S. (2007). Sikap Manusia Teori dan Pengukurannya, Edisi ke-2. Yogyakarta: Pustaka Pelajar Offset.

Bossola, M., Pepe, G., \& Vulpio, C. (2018). The Frustrating Attempt to Limit the Interdialytic Weight Gain in Patients on Chronic Hemodialysis: New Insights Into an Old Problem. Journal of Renal Nutrition, 28(5), 293-301.

Data Pusat dan Informasi Kementerian Kesehatan Republik Indonesia. (2017). Situasi penyakit ginjal kronis. Jakarta: Kemenkes $R$

Echder, Y., \& Schriner, R., (2012). Cardiovascular Abnormalites in Autosomal Dominant Polisistic Kidney Disease. Nat Rev Nephrol

Hartini, S., \& Sulastri, S. K. (2016). Gambaran Karakteristik Pasien Gagal Ginjal Kronis Yang Menjalani Hemodialisa Di Rumah Sakit Umum Daerah Dr. Moewardi (Doctoral dissertation, Universitas Muhammadiyah Surakarta).

Irianto, K. (2014). Anatomi Dan Fisiologi Edisi Revisi. CV. Alfabeta, Bandung.

Istanti, Y. P. (2013). Hubungan antara Masukan Cairan dengan Interdialytic Weight Gains (IDWG) pada Pasien Chronic Kidney Diseases di Unit Hemodialisis RS PKU Muhammadiyah Yogyakarta. Profesi (Profesional Islam): Media Publikasi Penelitian, 10(01).

Endang Sri Wahyuni' Prodi Gizi Poltekkes Tanjung Karang, Bandar Lampung, Indonesia.

Email: end_wahyuni71@poltekkes-tjk.ac.id

Siti Indarti ${ }^{2}$ STIKes Muhammadiyah Pringsewu, Lampung, Indonesia. Email: indartisiti74@gmail.com 
HUBUNGAN KARAKTERISTIK, PENGETAHUAN TENTANG ASUPAN NATRIUM DAN CAIRAN DENGAN INTERDIALYTIC WEIGHT GAIN (IDWG) PADA PENDERITA GAGAL GINJAL KRONIK YANG MENJALANI HEMODIALISIS (HD)

Istanti, Y.P. (2016). Faktor-Faktor yang Berkontribusi terhadap Interdialytic Weight Gains pada Pasien Chronic Kidney Diseases yang Menjalani Hemodialisis. Mutiara Medika: Jurnal Kedokteran dan Kesehatan, 11(2), 118-130.

Kalantar-Zadeh, K., Regidor, D. L., Kovesdy, C. P., Van Wyck, D., Bunnapradist, S., Horwich, T. B., \& Fonarow, G. C. (2009). Clinical perspective. Circulation, 119(5), 671-679.

Kamyar, K. Z. (2009). Interdialytic Weight Gain. Mortality Linked. Nephrology Nursing Journal.

Kristanti, H. (2006). Penyakit Akibat kelebihan \& Kekurangan Vitamin, mineral \& Elektrolit. Citra Pustaka, Yogyakarta.

Kurniawati, D. P., Widyawati, I. Y., \& Mariyanti, H. (2019). Edukasi dalam Meningkatkan Kepatuhan Intake Cairan Pasien Penyakit Ginjal Kronik (PGK) on Hemodialisis. Critical, Medical and Surgical Nursing Journal, 3(2).

Lindberg, M. (2010). Excessive Fluid Overload among Haemodialysis Patients: Prevalence, Individual Characteristics and Self-regulation of Fluid Intake (Doctoral dissertation, Acta Universitatis Upsaliensis).

Lindley, E. J. (2009). Reducing sodium intake in hemodialysis patients. In Seminars in dialysis (Vol. 22, No. 3, pp. 260-263).

Lolyta, R., \& Solechan, A. (2012). Analisis faktor yang mempengaruhi tekanan darah hemodialisis pada klien gagal ginjal kronik (studi kasus di RS Telogorejo Semarang). Karya IImiah S. 1 IImu Keperawatan.

Mann, J., \& Stewart, T. (2012). Buku Ajar IImu Gizi edisi 4. Jakarta: Penerbit Buku Kedokteran EGC.
Maria, G., Puspita, R. D., \& Sulistyowati, Y. (2012). Hubungan asupan natrium dan kalium dengan tekanan darah pada pasien hipertensi di unit Rawat jalan di rumah sakit guido valadares dili timor leste. Universitas Respati Yogyakarta.

Mc Causland, F. R., Waikar, S. S., \& Brunelli, S. M. (2012). Increased dietary sodium is independently associated with greater mortality among prevalent hemodialysis patients. Kidney international, 82(2), 204-211.

Moissl, U., Arias-Guillén, M., Wabel, P., Fontseré, N., Carrera, M., Campistol, J. M., \& Maduell, F. (2013). Bioimpedance-guided fluid management in hemodialysis patients. Clinical Journal of the American Society of Nephrology, 8(9), 1575-1582.

Mustikasari, I. (2017). Faktor-faktor yang mempengaruhi nilai interdialytic weight gain pasien hemodialisa di RSUD Panembahan Senopati Bantul. Gaster: Jurnal Kesehatan, 15(1), 78-86.

Nerbass, F. B., Morais, J. G., Santos, R. G. D., Kruger, T. S., Sczip, A. C., \& Luz Filho, H. A. D. (2013). Factors associated to salt intake in chronic hemodialysis patients. Brazilian Journal of Nephrology, 35(2), 87-92.

Neumann, C. L., Wagner, F., Menne, J., Brockes, C., Schmidt-Weitmann, S., Rieken, E. M., ... \& Haller, H. (2013). Body weight telemetry is useful to reduce interdialytic weight gain in patients with end-stage renal failure on hemodialysis. Telemedicine and e-health, 19(6), 480-486.

Notoatmodjo, S. (2010). Kesehatan IImu Masyarakat dan Seni.

Pranandari, R., \& Supadmi, W. (2015). Faktor risiko gagal ginjal kronik di unit hemodialisis RSUD Wates Kulon Progo. Majalah farmaseutik, 11(2), 316-320.

Endang Sri Wahyuni' Prodi Gizi Poltekkes Tanjung Karang, Bandar Lampung, Indonesia.

Email: end_wahyuni71@poltekkes-tjk.ac.id

Siti Indarti ${ }^{2}$ STIKes Muhammadiyah Pringsewu, Lampung, Indonesia. Email: indartisiti74@gmail.com 
HUBUNGAN KARAKTERISTIK, PENGETAHUAN TENTANG ASUPAN NATRIUM DAN CAIRAN DENGAN INTERDIALYTIC WEIGHT GAIN (IDWG) PADA PENDERITA GAGAL GINJAL KRONIK YANG MENJALANI HEMODIALISIS (HD)

Rahardjo, P., Susalit, E. \& Suhardjono.(2009). Hemodialisis. Buku Ajar IImu Penyakit Dalam

Rukmaliza, N. T., \& Kep, S. (2014). Hubungan karakteristik individu dengan kualitas hidup pasien gagal ginjal kronik yang menjalani hemodialisis dirninstalasi dialisis blud Rumah Sakit Umum Dr. Zainoel Abidinrnbanda Aceh Tahun 2013. ETD Unsyiah.

Suharyanto, T., \& Madjid, A. (2009). Asuhan Keperawatan Pada Klien Dengan Gangquan Sistem Perkemihan, Jakarta: Trans Info Media.

Vennegoor, M. A. (2009). Salt restriction and practical aspects to improve compliance. Journal of Renal Nutrition, 19(1), 63-68.
Wayunah, W., Saefulloh, M., \& Nuraeni, W. (2016). Penerapan edukasi terstruktur meningkatkan self efficacy dan menurunkan idwg pasien hemodialisa di rsud indramayu. Jurnal Pendidikan Keperawatan Indonesia, 2(1), 22-28.

Wong, M. M., McCullough, K. P., Bieber, B. A., Bommer, J., Hecking, M., Levin, N. W., \& Tomo, T. (2017). Interdialytic weight gain: trends, predictors, and associated outcomes in the international Dialysis Outcomes and Practice Patterns Study (DOPPS). American Journal of Kidney Diseases, 69(3), 367-379.

Wulan, S. N., \& Emaliyawati, E. (2018). Kepatuhan Pembatasan Cairan dan Diet Rendah Garam (Natrium) pada Pasien GGK yang Menjalani Hemodialisa. Faletehan Health Journal, 5(3), 99106.

Endang Sri Wahyuni' Prodi Gizi Poltekkes Tanjung Karang, Bandar Lampung, Indonesia.

Email: end_wahyuni71@poltekkes-tjk.ac.id

Siti Indarti ${ }^{2}$ STIKes Muhammadiyah Pringsewu, Lampung, Indonesia. Email: indarti.siti74@gmail.com 